\title{
Religiosity, Covid 19, and Death Threats in Indonesian Poetry
}

\author{
Erlis Nurmujiningsih ${ }^{1, *}$, Dina Amalia ${ }^{1}$, Mu’jizah Mu’jizah $^{1}$, Suryami Suryami ${ }^{1}$, \\ Erli Yetti ${ }^{1}$, Purwaningsih Purwaningsih ${ }^{1}$
}

\author{
${ }^{1}$ National Research and Innovation Agency, Indonesia \\ ${ }^{*}$ Corresponding author: erlisnur2021@gmail.com
}

\begin{abstract}
Covid is a scary pandemic. Millions of people died due to this disease. Although the vaccine has been injected, this disease still exists and is no cure. Fear haunts many people, and death spreads in many places. This condition brought people closer to God and inspired many poets to create poetry. Many of the covid poems were written by adults to children dan the poem can be read on FB and anthology of poetry. These poems were also widely discussed by literary critics, and their articles were published in journals. A book of covid poetry has also been published for school children. Now, the relation between covid, poetry, and death is very close. This study aims to explore a representation of religious death in covid poems. The method used a qualitative approach with a literature study. From the study results, it is known that poetry expresses feelings that were very close to the spiritual world. This spiritual world is a place to look for something that doesn't exist and has not been found. Therefore, when the deadly threat of covid appears, people become more religious, and covid poems become beautiful and aesthetic creativity.
\end{abstract}

Keywords: covid poetry, religiosity, representation, aesthetic

\section{INTRODUCTION}

Covid 19, which outbroke of Indonesia since the beginning of February 2020, is not over. The outbroke disease inspired writers to work in many genres of literature. Poetry and covid 19 become so close linkage today. Covid 19 emerges like a mushroom in Indonesian poems in 2020-2021. This poetry expresses the sadness of this long pandemic in the world. This disaster has also evoked the former Indonesian vice president, Jusuf Kalla, to write the poems published in his Instagram account. Children who are also vulnerable to this disease wrote the poems collected in an anthology. Ayo Lawan Covid 19 is the poem book published by Perkumpulan Stimulant Institute Sumba and Dinas Pendidikan Kabupaten Sumba Barat.

The anthology contains two volumes, each of which includes 29 children's poems. The category of the authors is children in the age of elementary school. The poems are collected in the event of the Literacy Festival in the ceremony of National Children Day. The selected poem is read when The President of the Republic of Indonesia attends.
The production of poetry related to the covid 19 continued in the middle of 2021. Some newspapers as yet broadcasted them as well as social media. The phenomena are understandable because the pandemic of covid 19 has destroyed all of the everyday life not only about health system but also economics as broaden the impact of the long catastrophe. Many people feel fear, worry because the death falls on their family and friends. In contrast, many people lose their jobs, and informal workers cannot earn money due to the policy of quarantine in the long periods, which results in disadvantages of economics. This misery appears in many expressions from the depth of the hearth in the poems. The famous author, Gus Mus or Mustofa Bisri, then voices the situation of the deadness posted on Facebook titled "Terkurung" [1]. Meanwhile, Achmad Munjdid writes Kabar Kematian [2] and Sunu Warsono's posts "Adakah" [3]. In addition, some collected poems has been published in the anthologies like Peradaban Baru Corona:Puisi 99 Wartawan Penyair [4], Antologi puisi Puisi:Covid19, Radang \& Ladang Kehidupan [5], Antologi puisi To Kill The Invisible Killer [6]. 
The discussion on the poem and covid 19 since 2020 until now has been done by many scholars. Some of them are interesting such as "An Attempt to Anticipate Against Covid 19 in the Era of Disruption Through Improvement of Poem Anthology Based on Ecopreneurship," written by Sani Aryanto and Nunuy Nurkaeti. Their research uses the R and D method published in July 2020 to develop children's poems in the anthology for curing Covid 19 patients of children [7]. While, other articles are intended for school learning, such as Aesthetic and Poem Meaning, For Covid 19 Without Complaint [8], and The implication of covid 19 in school learning [9]. Also, an article entitled "The Writing Poem Capacity in Theme of Pandemic Covid 19 of Students from Ten Class, SMK 2 in the Capital City of Bengkulu" [10], then The Image in the Metaphor of Poems About Covid 19 written by Elementary School Children" [11]. All of them come from the education field. Nonetheless, from the non-educational field is "Social Representation in Pandemic Covid 19 Era in The Anthology to Kill the Invisible Killer".

Death is part of the theme often talked about in poems. Sapardi Djoko Damono wrote "Pada Suatu Hari Nanti", and Goenawan Mohamad has Di Hari Kematian Baradita Katoppo". Both of them tried to mean what called the decease. For Goenawan Mohamad it was "Aku tinggalkan waktu, Tuanku/Itu bisa. Itu mungkin bisa"/ "I left the Time, My Majesty/ It could. It could be" $\%$ In the work of sapardi Djoko Damono, the death was "Jasadku tak akan ada lagi/Suaraku tak terdengar lagi/Impianku pun tak dikenal lagi/. There was no longer my body/ My voice was not heard anymore/ My dream also was not known anymore/. However, these works were created before the global society are not threatened by the disease situation. After the world is in danger of destruction by the illness, what the meaning of death is in the author's works, and how it links to religiosity. Here religious attitude is crucial because of the closeness between death and God in the world of view of the believers. In addition, referring to Mangun Wijaya in Pitri [12], all literary works are religious beliefs. Each good literary work is always transcendental, the spirit of reflection as a human being. Asarpin, in discussing Gunawan Mohamad, said that his religion is the poem that gives the quietest struggle at once the most private feeling [6]. The poem religion was the Tagore's, which did not place the religious values as a normative set with various rituals. The poem religion is closer to the appreciation or recognition with seeking of not finished yet, and perhaps never be finished.

\section{METHOD}

This qualitative research investigates and understands the meaning of phenomena that occurred either as individuals or groups from social and humanities issues [13]. It also tries to understand the humanities problem because of covid 19 expressed in the poems linked to religiosity and death. Referring to Yusuf, qualitative research attempts to decode the meaning of the occurrence and tries to sympathize with people in the phenomena [14]. The interaction is developed between the researcher and the poems created by the authors in the pandemic situation.

The way to collect the data used is literary and watch and note technique. The first referring to Arikunto in Andriyanto et al. [15] is by using various written sources to get the data from printed and digital like Facebook and other social media. Then, they are selected regarding the similar theme of death poems caused of covid 19. Furthermore, there is also supporting data, such as the comments about those poems. The second, referring to Subroto in Adriyanto et al. [15], watch and note technique are used to the primary sources, namely, the poem"Terkurung" written by Gus Mus, "Kabar Kematian" [2], and "Adakah" written by Sunu Wasono [3]. Also, several poems in the anthology of Peradaban Baru Corona: Puisi 99 Wartawan Penyair [4], and the anthology of Covid-19, Radang \& Ladang Kehidupan [5]. After that, the researchers made notes on essential points from the meaning of poems to understand the connectivity between death, covid 19, and religiosity, then put them on the table. Finally, all the data are interpreted, identified, and classified to get an explanation and conclusion.

As mentioned before, qualitative research uses the researcher as the instrument with a table to put the data. One of the things that are often doubted in qualitative research is the question of the validity of the research results. Therefore, it is necessary to test the validity of the research results in the way that Bungin [16] suggested, namely by examination techniques. The examination technique consisted of (1) extension of participation, (2) finding cycles of data similarity, (3) persistence of observation, (4) triangulation of researcher honesty, (5) checking through discussion, (6) negative case studies, (7), checking members, (8) triangulation of methods, (9) triangulation of data sources, (10) triangulation of data sources, (11) adequacy of references, (12) detailed descriptions, (13) reliance audits. There are only three things done in this research because the data is from documents. First, data are then exposed by the compatriot to be examined its validity. After that, the researchers explained the detailed description of the result with some proofs from the texts of the poems and discussed them. 


\section{RESULT AND FINDING}

Some poems will be discussed here namely, "Terkurung" by Gus Mus [1], "Adakah" by Sunu Wasono [2], and "Kabar Kematian" by Achmad Munjid 13]. Puisi "Terkurung" tries to play the word of tahniah, takziah, dan tausiah.

Terkurung

Karya Gus Mus

Terkurung di rumah

Lewat udara yang gerah

Dan hati gelisah

Rindu saling sapa

Melongok jendela penuh gairah

Tapi tiba-tiba tahniah

Kalian berubah takziah.

("Semoga kedamaian, rahmat,

dan berkah Allah

Bagi kalian "berubah

Menjadi "kami milik Allah

Dan kepadaNya kami kembali”)

Akankah takziah

Menjadi tausiah?

The word tahniah, and takziah in the poem represent turning situation suddenly, from positive feeling from the word tahniah that means to greet other people peacefully at the time of extended quarantine at home to avoid virus contagion. Still, then that word becomes tahziah which is the kind of bad news. Takziah refers to death, which in literal meaning is human owned by the God whom He will take. Takziah also has an ordinary meaning that people in normal situations should visit the family who lost the member because of death. Meanwhile, tahniah is reverse to takziah. In the law of Islam, saying tahniah is sunnah because it integrates between tabrik and praying from a Muslim to each other due to happiness things. The word tahniah contains the meaning of mawaaddah, tarahum (love each other), and ta'athuf (empathy) among Muslims [17].

The paradox tone in that poem expresses the pain, how the I lyric feels lost, unhappy, disappointed to hear the fact of bad news from the hope of happiness. When I lyric wants to experience the freedom from the cage of quarantine after several days or weeks there, it means boring, pain, lonely, but then he/she just gets the other of suffering. Losing someone is sorrow; moreover, it is caused by the pandemic called a disaster. The lyric impresses that in the pandemic situation, humans do not enjoy, even any hope or dystopia, an unnormal or unideal condition. The message will be understandable by the readers living in the same condition. People feel similar tenses, threatened and stressed. The tone that is dominated by the nature of the pandemic is powerful, so people have difficulties detaching and finding the truth. The other poem owned by Bambang Widiatmoko, "Negeri yang Aneh" tries to find the cover of the truth. Aku mencoba terus mencermati keadaan dan mengurangi kepanikan/Berbagi sedikit rezeki bagi pemulung-pemulung yang mulai kelaparan/menahan cibiran tetangga yang diamdiam melaksanakan salat di/ masjid/menahan godaan dari perkataan mati yang menentukan adalah Tuhan/berharap memperoleh kemenangan melawan musuh yang tak kelihatan/ [1].

Widiatmoko's poem explains that the vagueness of the truth emerges because people have trouble differentiating what is proper to do. The covid 19 is the unseen enemy. People were confused at the beginning period of a pandemic when they watched television news. At the same time, the poem of Gus Mus is written in the second wave of covid 19, when the rate of death increases, so it shows dying everywhere. People experience by themselves the loss of their love without watching the news on television. Social media that replace television are closer to being read, informing the grieve announcements from relatives and friends. Then, Achmad Munjid writes "Kabar Kematian" [2]. "Mula-mula ia hanya jadi headline berita/yang kita baca sepintas-sepintas, setengah terjaga/...Baru saja kudengar kabar kematian seorang teman/yang dulu sering kita ajak jalan ke mana-manal [2]. This poetry illustrates other dystopias when there is still unfair competition in the emergency. Munjid especially mentions the official government who controls the chaotic bureaucracy, unhuman rules, and the officials who are not capable and do not stand in people [18]. /Sebagian lainnya menyulap kabar kematian/ menjadi energi dan kesempatan untuk melawan/untuk kepentingan politik, untuk keuntungan dagang/untuk memuaskan dendam yang lama terpendam/Orang-orang pun terbelah/Politikus dan pedagang saling bantah/ilmuwan dan agamawan saling sanggah/pejabat dan pengamat saling debat/ [2]. 
Typically, this poetry presents the death issue from the word takziah. Indeed, dying is inevitability, a path toward the divine. Apakah kaulihat betapa pada kenyataan yang serbasementara/pada fakta perubahan ini, tersembunyi Yang Ilahi/di depan kematian tidakkah kau saksikan betapa/yang maya berbaris rapi menuju Yang Hakiki/ [2]. Munjid says, the life in the world is mortal, temporary. The death is real, going to eternality. Nevertheless, the changing caused the pandemic has shocked many people, until man has no word to say, like Sunu Warsono's poetry, Tiba-tiba saja beribu kata di kamus/itu seperti kehilangan arti/...Aku ingin menemukan kata lain/selain ikhlas/dan legowo di saat diri kehilangan/sahabat/Adakah.../ [3].

The number of mortality rates makes people hear the death news in the second wave in 2021. The repeated reports from social media have a different meaning for people. When they should quarantine at home, but every day read the death reports from social media, shows how it is ether crucial or on the other hand has controlled the thought of people. What can be said is living under the rule of social media gives people fear and anxiety Salam calls it dystopia [18]. Despite a few people having little hope, they ask whether it is reached. Achmad Munjid's poem says that the hope quite the opposite makes man desperate. Coba kaujawab, apa gunanya memelihara ingatan/jika ia hanya mengekalkan rasa bersalah dan siksa/jika harapan hanya membuat kita merasa putus asa/ Di depan kematian, selain momen tak ada yang nyata/sebab di sini, tak ada lagi waktu/ [2].

The opinion in the poem expressed by Munjid in 2021 is different from the poet's thought in 2020 about covid 19. Ayu Cipta in 2020 said, "Elegi Covid 19". /Aku terbata dalam kata/Doa terlontar/Kepada langit kupasrahkan/Jiwa bersedekap/Tuhan/Dalam rengkuh cahayaMu/Bebaskan dunia dari corona/ [19]. At the beginning of the pandemic, the hope's tone was still optimistic. In praying, the expectation to God that He would eliminate the virus. After a year, the virus is getting fierce, people ask about the afterlife.

The mortal problem due to covid 19 actually has been talked in 2020 emerged in the anthology Peradaban Baru Corona:Puisi 99 Wartawan Penyair [4]. "Dingin dalam Api" by Asro Kamal
Rokan said Kami tidak lagi peduli/apakah ini konspirasi,/yang pasti perjalanan ini sepi/dalam terowongan pengab/Kematian dapat menyergap/di setiap dinding, tibatiba/Sungguh kematian itu pasti/ditulis dalam firmanMu/Kami tak mungkin lari/selangkah atau sedetik pun/. At the time the dying caused by the virus of covid 19 was interpreted as usual. Corona just one of the causes. Hence, the poet said that corona was not terror.

The condition how the body's funeral was planted, was showed by Amir Machmud NS in the poem "Semesta Misteri yang Terbaca Samar". He said manusia kembali ke haribaan/yang mati pergi tanpa upacara/. Similar tone with "Catatan Kecil" by Asril Koto who wrote, /sekian ribu kita menutup mata/isak tangis menjauh/jauh dari peti mati/. Both of them in 2020 illustrated the condition of the death cause of corona [19].

The problem of death emerges yet in the anthology of Covid-19, Radang \& Ladang Kehidupan [5]. The poem of Rebbeca Arju, "Gemuruh" express Kau datang, tanpa ku sadari/Mengurangi penduduk bumi dari setiap tepi/. The death in that poem is meant to decrease the world population. While, the death in 2020 is messaged only as reports is told in "Belajar dari Covid 19" by Utami Widiati /Tapi dampakmu begitu dashyat/Dari hari ke hari terdengar berita menyayat/Tentang bertambahnya jumlah kehilangan jasad/. The information of the mortal for I lyric in this poem limits on the knowledge in the number in the media. Unlike the poems written in 2021 which talk about death in a very close way due to the report of social media accessed from the personal gadget, each person who informs the dying man is family and friends.

The drawing about dying in the poems of Indonesian poets, who have a set of values such as religiosity, indicates that the literary works have interlinkage. Bachtiar said, in the Koran, holy writing has the most beautiful literary work created by God [20]. The other scripture, like the Bible and Bhagawat Ghita, also contains the high art of writing. The word of religion comes from Latin relegere or relegare meant to be careful and hold on to the norms or law strictly [21]. Religare refers to binding self to the holy invisible power, which is believed as the Director of the cosmos, including man. While, Gazalba in Sari said that religious feeling is the tendency of spiritual human-related 
to the cosmos, which in values include all the things, the final meaning, and the existence of all. Religion connects to the Holy, that human depends on Him, hope the blessing from Him by applying the law, rituals, and other religious behavior [21].

Regarding some definitions of religion, the essence is the holy Power beyond human. In the pandemic, people who live in suffer try to be closer to that power, to hope salvation, sanity, and cure by praying. Some poems which publish in the anthology of Peradaban Baru Corona:Puisi 99 Wartawan Penyair shows the recognition of beyond the human power in the poem worked by Dimas Agoes Pelaz, "Jerit Corona and Do'a", bersijingkat/Semua lebur meyatu dalam/permohonan/, and in the anthology of poems about covid 19, Radang \& Ladang Kehidupan [4] in "Belajar dari Covid-19" by Utami Dewi Hanya mampu diriku berdo'a/Yakin hanya do'a yang dapat mengubah qadal.

However, the question risen is whether the religiosity is only signed by praying. Some poets give the opinion through the poems "Sabda Bumi" by Gus Mus published in the Anthology of Peradaban Baru [4]. The reflection deliberated in that poem is the corona virus signs that the earth has been exhausted because of human's behavior. Berkelahi sesama hamba Allah menguras bukan mengurus bumimu/. Other poem says, "Melihat Tuhan yang Menyembuhkan Bumi" by Ryan Rachman /Bumi telah lama sakit/Sejak manusia tak lagi asyik jadi manusia/Manusia lupa bagaimana menjadi manusia/. The poem "Catatan Kecil" by Asril Koto said the same things, Tuhan lewat wabah/memberi sinyal:/ia meminta jalan hidup tak bergelombang/...dan meralat kekhilafan/.

The reflections tended to correction of human self to other people and the human's existence in the world. The message of Gus Mus Poem is also tausiah that he mentions in the poem of "Terkurung". Tausiyah refers to Indonesian dictionary means "message". The word tausiah comes from Arabic, which means advice, which is similar to the word tablig or religious lecture in spreading Islam. Practically, tausiah contends religious lecture, which provides the words of the truth and patience.

The result of tausiah is good to understand or self-awareness in the spirit to solve the problem.
Tausiah can be implemented in several ways, formally often in the religious lecture, but the poet also can do the duty of the religious lecturer named Kyai through the poems. The poem, as one of the kinds literary works naturally has dulce et utile, entertaining and valuable. So, religiosity is about praying and the connectedness between humans and the Creator, human and human, human and other creatures, including the environment.

Covid 19 was associated with death, especially in 2021. The poem of "Terkurung" argues that humans should reflect the dying, and this poem is like tausiah for people who read it. Tausiah from Gus Mus in that poem shows a solution to dystopia today. Tausiah becomes positive energy to charge the exhausted human.

\section{CONCLUSION}

The disaster which occurs now in the world is part of the nature to human corrects their-selves. Gus Mus is one of the poets who wrote the poem of "Terkurung" messages it published on Facebook. other poems talked about the confusion, the fear, and little express about hope. The transcendental nature of poems related to the Facebook is important to see the spreading of the poems so people can widely read this message. From the study results, it is known that poetry expresses feelings that were very close to the spiritual world. This spiritual world is a place to look for something that doesn't exist and has not been found. Therefore, when the deadly threat of covid appears, people become more religious, and covid poems become beautiful and aesthetic creativity.

\section{REFERENCES}

[1] M. Bisri, "Terkurung”. Facebook. 22 July 2021

[2] A. Mundjid, "Kabar Kematian". Jawa Pos, Saturday, 24 July 2021.

[3] S. Wasono, “Adakah”. Facebook 27 July. 2021.

[4] A. Tan. "Peradaban Baru Corona: Puisi 99 Wartawan Penyair". Anugerah Jaya Media. 2020.

[5] R. Arju,"Antologi Puisi Covid-19: Radang \& Ladang Kehidupan". Jember:Pustaka Abadi. 2020.

[6] FX R. Gunawan \& A. Malay. "To Kill The Invisible Killer" Gramedia. 2020 
[7] S. Aryanto, Rahman, N. Nurkaeti, Z. T. Rony, Suharjuddin, D. A. M. Lidinillah, and F. Junaidi. "Internalization of Ecopreneurship Values through the Development of Poetry Anthology in Primary School." In Proceedings of the 2nd Borobudur International Symposium on Humanities and Social Sciences. 2021.

[8] Salami, "Aesthetic and Poem Meaning, For Covid 19 Without Complaint", Jurnal Lateralisasi Vol. 08 No. 02, 2020

[9] Elyusra, "The Implication of Covid 19 in School Learning" Jurnal Lateralisasi Vol. 08 No. 02, 2020

[10] N. F. Yanti, D. Yulistio, \& A. J. Purwadi "The Writing Poem Capacity in Theme of Pandemic Covid 19 of Students from Ten Class, SMK 2 in the Capital City of Bengkulu" Journal Korpus Vol. 4, No. 3, 2020

[11] Herwan \& Devi "The Image in the Metaphor of Poems About Covid 19 Written by Elementary School Children" Journal Diglossia Vol.3 No. 4, 2020

[12] I. Pitri, “Aspek Religiusitas dalam Kumpulan Puisi Topeng: Tinjuan Tema". Thesis. Sastra Indonesia, Fakultas Ilmu Budaya, Universitas Andalas, Padang. 2011.

[13] S. K. Santana, "Menulis Ilmiah:Metodologi Penelitian Kualitatif'. Yayasan Pustaka Obor Indonesia. Jakarta. 2010.

[14] M. Yusuf, "Metode Penelitian Kuantitatif, Kualitattif \& Penelitian Gabungan". Prenada Media Grup, Jakarta, 2014.
[15] M. Adriyanto, Mega, F. Meliasanti, Sutri. "Representasi Sosial Masa Pandemi Covid-19 dalam Antologi Puisi To Kill the Invisible Killer Karya F.X Rudy Gunawan dan Afnan Malay”. Jurnal Bahasa dan Sastra Vol. 9, No. 1, 2021. pp. 35-46. DOI:1024036/jbs.v9i1.111535

[16] B. Bungin, "Penelitian Kualitatif: Komunikasi Ekonomi, Kebijakan Publik, dan Ilmu Sosial lainnya. Prenada Media Grup. Jakarta. 2011.

[17] About Dunia. Arti Tahniah. in https://aboutdunia.blogspot.com /2017/11/artitahniah.html 2021.

[18] A. Salam, \& C. S. Barringer, "Pandemi sebagai Distopia”. Proceedings Seminar Nasional Model Humanisasi untuk Menyiasati Pandemi, Forum Humaniora Nusantara, 2021.

[19] R. Sylado, Remi. Peradaban Baru Corona:Puisi 99 Wartawan Penyair. PT Anugerah Jaya Media. Jakarta. 2020.

[20] A. Bachtiar, "Religiusitas Masyarakat Jawa dalam Karya Sastra Indonesia Modern”. Deiksis Vol.3, No. 4. 2011. pp. 339-353. DOI:10.309998/deiksis.v3i04.439.

[21] J. L. Sari, "Hubungan Religiusitas terhadap Pengambilan Keputusan dalam Memilih Pasangan Hidup Mahasiswi Psikologi UIN Maulana Malik Ibrahim Malang”. Thesis. Fakultas Psikologi Universitas Islam Negeri Maulana Malik Ibrahim, Malang. 2014. 